\title{
Transmission of iridovirus from freshwater ornamental fish (pearl gourami) to marine fish (rock bream)
}

\author{
Joon Bum Jeong ${ }^{1}$, Hye Jin Cho ${ }^{2}$, Lyu Jin Jun ${ }^{2}$, Su Hee Hong ${ }^{3}$, Joon-Ki Chung ${ }^{2}$, \\ Hyun Do Jeong ${ }^{2, *}$
}

${ }^{1}$ Faculty of Applied Marine Science, College of Ocean Science, Cheju National University, Ara 1 dong, Jeju-do 690-756, South Korea

${ }^{2}$ Department of Aquatic Life Medicine, Pukyong National University, Daeyeon 3 dong, Nam-gu, Busan 608-737, South Korea

${ }^{3}$ Faculty of Marine Bioscience and Technology, Kangnung National University, Kangnung 210-702, South Korea

\begin{abstract}
Freshwater pearl gourami Trichogaster leeri and seawater rock bream Oplegnathus fasciatus infected by the iridoviruses PGIV-SP and IVS-1 were carrying similar numbers of viral particles $\left(2.52 \times 10^{8}\right.$ and $2.46 \times 10^{8}$ viral genome copies $\mathrm{mg}^{-1}$ spleen tissue, respectively). The viral genome copy number for both iridoviruses decreased much faster in seawater than in freshwater, reaching a concentration of less than $0.5 \%$, versus 26 to $54 \%$ in freshwater, after $4 \mathrm{~d}$ of incubation at $25^{\circ} \mathrm{C}$. The decrease in copy number altered the infectivity of the viruses, as reflected by the decreased cumulative mortality of rock bream injected intraperitoneally with the incubated iridoviruses. Moreover, uninfected rock bream cohabitated with PGIV-SP-challenged rock bream showed $100 \%$ cumulative mortality; a similar experiment using IVS-1 had the same result, implying the potential for iridoviral transmission from freshwater ornamental fish to marine fish even in a marine environment. Of 58 outwardly healthy marine fish groups collected from various markets, 2 rock bream groups and 1 sea perch group Lateolabrax sp. tested positive for PGIV-SP by 2-step polymerase chain reaction (PCR). Thus, PGIV-SP from freshwater ornamental fish may have crossed both environmental and species barriers to infect marine fish such as rock bream.
\end{abstract}

KEY WORDS: Cross-infection · Cohabitation · Megalocytivirus $\cdot$ Real-time PCR · Pearl gourami Trichogaster leeri $\cdot$ Rock bream · Oplegnathus fasciatus

Resale or republication not permitted without written consent of the publisher

\section{INTRODUCTION}

Over the last 2 decades, viruses of the Iridoviridae family have emerged as a major threat to the marine aquacultural industry in multiple countries, affecting both wild and freshwater ornamental fishes (Inouye et al. 1992, Bloch \& Larsen 1993, Chua et al. 1994, Paperna et al. 2001). Since red seabream Pagrus major iridovirus (RSIV) was first detected in Japan in 1990 (Inouye et al. 1992), several iridoviruses have been isolated, including infectious spleen and kidney necrosis virus (ISKNV), largemouth bass Micropterus salmoides salmoides virus (LMBV), African lampeye
Aplocheilichthys normani iridovirus (ALIV), dwarf gourami Colisa lalia iridovirus (DGIV), rock bream Oplegnathus fasciatus iridovirus (RBIV), grouper Cromileptes altivelis sleepy disease virus (GSDIV), and RBIV IVS-1 (He et al. 2000, Hanson et al. 2001, Sudthongkong et al. 2002, Do et al. 2004, Mahardika et al. 2004, Jeong et al. 2006a). Iridoviral replication via cell culture is inefficient; thus, each of these viruses is difficult to cultivate in vitro (Nakajima \& Sorimachi 1994, Chou et al. 1998).

The International Committee on Taxonomy of Viruses (ICTV) currently recognizes 5 genera within the family Iridoviridae: Iridovirus, Chloriridovirus, 
Ranavirus, Lymphocystivirus, and Megalocytivirus. The latter 3 contain taxa that infect finfish (Chinchar et al. 2005), including Megalocytivirus, which was only recently identified (Chinchar et al. 2005). ISKNV, isolated from mandarinfish Siniperca chuatsi in China (He et al. 2002), was selected as the type species of the genus Megalocytivirus.

Viruses of the Iridoviridae family are also notable because they can infect a wide assortment of hosts, causing diseases that range in severity from subclinical to lethal (Williams 1996). We previously reported a high frequency of IVS-1 infections with/without clinical symptoms in various cultured marine fish, including market-size adults and young-of-year juveniles (Jeong et al. 2006b).

Molecular genetic approaches are routinely used in epidemiological studies to identify possible sources of infection. To determine the phylogenetic relationships between iridoviruses, or for detection of a given iridovirus, previous studies have used polymerase chain reaction (PCR) with primers specific for various genes, including major capsid protein (MCP) (He et al. 2001), ribonucleotide reductase small subunit (RNRS) (Oshima et al. 1998), DNA polymerase (DPOL), adenosine triphosphatase (ATPase), the Pst I restriction fragment (Kurita et al. 1998), and K2 region (Jeong et al. 2006a). However, PCR-based assays are only able to detect the presence of an iridoviral infection, and not the viral load in the infected fish, which may be a useful indicator of disease outbreaks. Recently, real-time PCR techniques involving the use of hybridization probes or double-stranded DNA binding dyes have been increasingly used for the routine diagnosis and quantitation of aquatic viruses (Munir 2006, Nerland et al. 2007, Pallister et al. 2007).

There is an obvious risk that an imported virus might infect some other important species in aquatic industries. The pathogenicity of ISKNV was examined in mandarinfish and in 20 other species of commercially important marine and freshwater fishes, and, except for mandarinfish and largemouth bass, none of the species that were previously reported to be susceptible to iridoviruses was found to be susceptible to ISKNV (He et al. 2002). Still, recent research suggests that many marine fish are infected by viruses whose clinical symptoms are similar to those caused by ISKNV (Weng et al. 2002, Chen et al. 2003). These viruses, which are referred to as ISKNV-like viruses, were recently detected in $14.6 \%$ of cultured and wild marine fish by 2-step PCR (Wang et al. 2007). However, few experiments have shown the infectivity of iridoviruses derived from freshwater (or marine) fish hosts in marine (or freshwater) fish. Additional analyses are required to determine the potential risk of mass mortality in commercially important marine fish due to
Megalocytivirus spp. derived from freshwater ornamental fish.

The aim of the present study was to compare the potential for iridoviral transmission under various conditions and evaluate the virulence of PGIV-SP from freshwater ornamental fish and IVS-1 from marine fish, when used to infect other fish species in order to identify possible sources of cross-infection.

\section{MATERIALS AND METHODS}

Fish. Pearl gourami Trichogaster leeri (mean body mass $4.0 \pm 1.0 \mathrm{~g}$ ) and rock bream Oplegnathus fasciatus $(6.0 \pm 1.0 \mathrm{~g})$ were obtained from an ornamental fish shop and a marine fish farm, respectively, in Korea. The fish were kept in 401 tanks filled with freshwater or seawater at $25^{\circ} \mathrm{C}$ i the water was changed 3 times per day. After $3 \mathrm{wk}$, we removed spleens from 10 fish of both species and confirmed that they were free of iridovirus by 2-step PCR using the SP1F/SP1R and SP2F/SP2R primer sets (Table 1) as described below.

Virus preparation. PGIV-SP was obtained from pearl gourami $(4.0 \pm 1.0 \mathrm{~g})$ showing signs of mass mortality $14 \mathrm{~d}$ after arriving in Korea from Singapore in 2005. Histopathological analyses revealed enlarged cells in the spleen, and PCR amplification of the ORF (Open Reading Frame)-1 gene using the SP1F/SP1R primer set (Table 1) was used to diagnose all cases of iridovirus infection. Infection of rock bream (100 \pm $10 \mathrm{~g})$ with IVS-1 was determined as previously described (Jeong et al. 2006b). Homogenates were prepared from the spleens of pearl gourami and rock bream experimentally infected by intraperitoneal (IP) injection with PGIV-SP and IVS-1, respectively. Briefly, splenic tissue was removed from 10 fish at the moribund stage and ground in 20 volumes of phosphate-buffered saline (PBS) (0.1 M [pH 7.2]) in a tube with a fitted pestle (Sigma-Aldrich) and then centrifuged at $300 \times g$ for $5 \mathrm{~min}$. The supernatant was then filtered through a membrane $(0.45 \mu \mathrm{m}$ pore size $)$ to create $50 \mu \mathrm{l}$ aliquots, which were stored at $-80^{\circ} \mathrm{C}$ until use.

PCR. Total genomic DNA was extracted from the spleens of infected fish using an AccuPrep Genomic DNA Extraction Kit (Bioneer) and dissolved in distilled water $\left(100 \mu \mathrm{g} \mathrm{ml}^{-1}\right)$. Single-step PCR was carried out in a $50 \mu$ reaction mixture containing $0.5 \mu \mathrm{l}$ of genomic DNA, $10 \mathrm{mM}$ Tris- $\mathrm{HCl}$ (pH 8.3), $50 \mathrm{mM} \mathrm{KCl}, 1.5 \mathrm{mM}$ $\mathrm{MgCl}_{2}, 0.001 \%$ w/v gelatin, 0.5\% Tween-20, $200 \mu \mathrm{M}$ each dNTP, $1 \mu \mathrm{M}$ each single-step PCR primer (Table 1), and 1.25 U of AmpliTaq DNA Polymerase (PE Applied Biosystems) using a Perkin-Elmer 2400 thermal cycler. After 2 min of predenaturation at $95^{\circ} \mathrm{C}$, the mixtures were incubated for 30 cycles at $95^{\circ} \mathrm{C}$ for 
Table 1. Primers used in the present study

\begin{tabular}{|c|c|c|c|c|}
\hline Target & Object & Primer & $\begin{array}{l}\text { Oligonucleotide sequence } \\
\text { (5' to } 3^{\prime} \text { direction) }\end{array}$ & Expected size \\
\hline ORF-1 of K2 region & Detection & $\begin{array}{l}\text { SP1F } \\
\text { SP1R } \\
\text { SP2F } \\
\text { SP2R }\end{array}$ & $\begin{array}{l}\text { CAAGGTAGACCACATCCAG } \\
\text { GTCATGTTGCATGTATATG } \\
\text { GTGTGGATGACATAAGTC } \\
\text { CACACTAACACACTACG }\end{array}$ & $\begin{array}{c}1130 \mathrm{bp}^{\mathrm{a}} \\
\text { (1-step PCR) } \\
531 \mathrm{bp}^{\mathrm{a}} \\
\text { (2-step PCR) }\end{array}$ \\
\hline ORF-2 of $\mathrm{K} 2$ region & $\begin{array}{l}\text { Differentiation } \\
\text { (PGIV-SP) }\end{array}$ & $\begin{array}{l}\text { PGV1F } \\
\text { PGV1R } \\
\text { PGV2F } \\
\text { PGV2R }\end{array}$ & $\begin{array}{l}\text { AGTGTCTGGATGAGTGTGTC } \\
\text { CGCAGAAGCCAGTTG } \\
\text { GATATTATAAAGCCCGTG } \\
\text { CGGTATAGTTCATAAA }\end{array}$ & $\begin{array}{c}509 \mathrm{bp} \\
\text { (1-step PCR) } \\
273 \mathrm{bp} \\
\text { (2-step PCR) }\end{array}$ \\
\hline ORF-2 of $\mathrm{K} 2$ region & $\begin{array}{l}\text { Differentiation } \\
\quad \text { (IVS-1) }\end{array}$ & $\begin{array}{l}\text { IVS1F } \\
\text { IVS1R } \\
\text { IVS2F } \\
\text { IVS2R }\end{array}$ & $\begin{array}{l}\text { AGTGTCTGGACGATAAGATG } \\
\text { CGCTTGAGCCGTATG } \\
\text { GATATTATCAGGCCGAAG } \\
\text { TAGTCATGTCTACATG }\end{array}$ & $\begin{array}{c}602 \mathrm{bp} \\
\text { (1-step PCR) } \\
273 \mathrm{bp} \\
\text { (2-step PCR) }\end{array}$ \\
\hline
\end{tabular}

$30 \mathrm{~s}, 55^{\circ} \mathrm{C}$ for $30 \mathrm{~s}$, and $72^{\circ} \mathrm{C}$ for $30 \mathrm{~s}$, followed by a final extension at $72^{\circ} \mathrm{C}$ for $7 \mathrm{~min}$. For 2 -step PCR, the above conditions were used except that in the second round of amplification, $0.5 \mu$ l of the reaction mixture from the first round was used as the template, and the primers used were designed to anneal within the amplicons from the first round. The amplified products were analyzed by $1 \%$ agarose gel electrophoresis.

Nucleotide sequence determination. The PCR products were purified by agarose gel electrophoresis using a Prep-A-Gene DNA Purification System (BioRad Laboratories) and cloned into TOPO-TA (Invitrogen) according to the manufacturer's instructions. Each clone was sequenced using a Big Dye Terminator Cycle DNA Sequencing Kit (ABI PRISM, PE Applied Biosystems) and an automatic sequencer. All nucleotide sequences and their deduced primary sequences were compared by alignment using the MACAW program (Version 2.0.5, National Center for Biotechnology Information, National Institutes of Health).

Viral stability. The infected spleen homogenates were used to assess the stability of the viruses in seawater and freshwater. The filtered spleen homogenates were added to $10 \mathrm{ml}$ of filtered seawater or freshwater (corresponding to infected spleen $1 \mathrm{mg}$ $\mathrm{ml}^{-1}$ ) and incubated for $4 \mathrm{~d}$ at $25^{\circ} \mathrm{C}$. To determine filtration effects, $10 \mathrm{mg}$ homogenates in $1 \mathrm{ml}$ of PBS $(0.1 \mathrm{M}$ [pH 7.2]) were prepared before and immediately after filtration (before filtration and Day 0, respectively). Viral stability was evaluated by real-time PCR and by viral challenge.

Real-time PCR: Total genomic DNA was extracted from tissue homogenates prepared before filtration, on Day 0, and on Day 4 from fish incubated at $25^{\circ} \mathrm{C}$ in seawater or freshwater using an AccuPrep Genomic DNA Extraction Kit (Bioneer) and quantitated using the
Quant-i $\mathrm{T}^{\mathrm{TM}}$ PicoGreen ${ }^{\circledR}$ dsDNA Reagent and Kit (Invitrogen) according to the manufacturer's instructions. To quantify the iridoviral DNA present in the homogenate, real-time PCR was performed using a Rotor-Gene 6000 (Corbett Research) according to the manufacturer's instructions. The reaction mixture contained $1 \times$ Eva Green dye, $1 \times$ PCR buffer (10 mM Tris$\mathrm{HCl}$ [pH 8.3] and $50 \mathrm{mM} \mathrm{KCl}), 2.5 \mathrm{mM} \mathrm{MgCl}_{2}, 0.3 \mathrm{mM}$ dNTPs, $0.5 \mathrm{pM}$ each primer, $2.5 \mathrm{U}$ of Taq DNA Polymerase, and $1 \mu \mathrm{g}$ of template DNA in a total volume of $20 \mu$ l. The amplification conditions were as follows: $94^{\circ} \mathrm{C}$ for $10 \mathrm{~min}$ followed by 40 cycles at $94^{\circ} \mathrm{C}$ for $10 \mathrm{~s}$, $52^{\circ} \mathrm{C}$ for $15 \mathrm{~s}$, and $72^{\circ} \mathrm{C}$ for $20 \mathrm{~s}$. No evidence of nonspecific amplification was found. As a positive control, recombinant TOPO-TA containing $166 \mathrm{bp}$ from the MCP gene amplified using the primers MR1F (5'AGATGATTGGCATGCGCAGC-3') and MR1R (5'AGCTTGAAGTGGATGCGCAC-3') was purified from transformed Escherichia coli DH5 $\alpha$. A serial 10-fold dilution of the control plasmid $\left(5.0 \times 10^{9}\right.$ to $5.0 \times 10^{1}$ copies $\mu \mathrm{l}^{-1}$ ) was used to establish a standard curve. The standard curve, which was generated using the mean data from experiments performed in triplicate, indicated a good linear relationship between the threshold cycle $\left(C_{\mathrm{T}}\right)$ value and the logarithmic plasmid concentration (data not shown).

Viral challenge: Fifteen rock bream were challenged by IP injection with $0.1 \mathrm{ml}$ of the PGIV-SP or IVS-1-infected tissue homogenates (corresponding to $100 \mu \mathrm{g}$ infected spleen per fish) which were incubated at $25^{\circ} \mathrm{C}$ for $0,1,2,3$, and $4 \mathrm{~d}$ in seawater or freshwater before injection. Sterile PBS $(0.1 \mathrm{ml}$ [pH 7.2]) was also injected intraperitoneally into 15 other rock bream and pearl gourami as negative controls. After the challenge, 22 groups of fish were each maintained at $25^{\circ} \mathrm{C}$ in a $40 \mathrm{l}$ tank for $3 \mathrm{wk}$. The water was changed daily 
and the fish were fed commercially prepared pellets once a day. Iridovirus infection was confirmed by PCR using the primers SP1F and SP1R (Table 1) and by histopathological observation.

Cohabitation experiments. Pearl gourami and rock bream infected with PGIV-SP or IVS-1 were used for cohabitation experiments. A plastic net cage divided into 2 parts was placed inside a $100 \mathrm{l}$ rectangular tank. Fifteen fish injected intraperitoneally with $0.1 \mathrm{ml}$ of filtered tissue homogenate infected by PGIV-SP (corresponding to $100 \mu \mathrm{g}$ infected spleen per fish) were placed on one side, while 10 iridovirus-free fish of the same species were placed on the other side. Fifteen fish of the same species were also injected intraperitoneally with $0.1 \mathrm{ml}$ PBS ( $\mathrm{pH} \mathrm{7.2)} \mathrm{and} \mathrm{held} \mathrm{in} \mathrm{a} \mathrm{sepa-}$ rate $100 \mathrm{l}$ tank as a negative control. The cohabitation experiment using IVS-1 was performed using the same method. The tanks were maintained at $25^{\circ} \mathrm{C}$ for $25 \mathrm{~d}$ and dead fish were removed daily. Iridovirus infection was confirmed by PCR using the primers SP1F and SP1R (Table 1) and by histopathological observation.

Sample processing. To search for asymptomatic iridovirus infections among marine fish, 35 and 23 groups of rock bream $(200 \pm 100 \mathrm{~g})$ and sea perch Lateolabrax sp. $(800 \pm 300 \mathrm{~g})$, respectively, were collected from 13 live-fish markets throughout 2006. Three fish from each group were tested for the presence of iridovirus in the spleen by single-step PCR using 3 different sets of primers or by 2-step PCR using 3 additional primer sets following the first round of amplification (Table 1). Infection was defined as even one positive PCR result. The amplified products were sequenced as described above.

\section{RESULTS}

\section{Stability and quantitation of the iridoviruses}

As shown by real-time PCR, the viral genome copy numbers for PGIV-SP in pearl gourami $(4.0 \pm 1.0 \mathrm{~g})$ and IVS-1 in rock bream $(6.0 \pm 1.0 \mathrm{~g})$ at the moribund stage were similar $\left(2.52 \times 10^{8}\right.$ and $2.46 \times 10^{8}$ viral genome copies $\mathrm{mg}^{-1}$ spleen tissue, respectively). Determined numbers of viral particles after filtration appeared to be very low compared to those of the samples before filtration, either because of the small volume of sample (10 mg homogenate in $1 \mathrm{ml}$ of PBS) or because filtration removed cellular debris which contained the virus (Table 2).

To compare the stability of the 2 iridoviruses, tissue homogenates were discharged into seawater and freshwater and incubated for $4 \mathrm{~d}$ at $25^{\circ} \mathrm{C}$ (Table 2). Decreased numbers of both iridoviruses were found in seawater after $4 \mathrm{~d}$ of incubation (less than $0.5 \%$ of the control, Day 0). In contrast, after $4 \mathrm{~d}$ of incubation in freshwater, the copy number of both iridoviruses was more than $25 \%$ that of the control (Day 0). No dramatic differences in terms of inactivation pattern, i.e. rapid inactivation in seawater but not in freshwater, were detected between PGIV-SP and IVS-1.

\section{In vivo analysis of residual and cross infection}

Aliquots of the virus-infected tissue homogenates were injected intraperitoneally into rock bream to examine the residual infectivity of iridoviruses incubated in seawater/freshwater for various periods of time based on the induced cumulative mortality (Fig. 1). As expected from our in vitro results showing the viral copy numbers in the tissue homogenates, the infectivity of both PGIV-SP and IVS-1 (1 $\left.\mathrm{mg} \mathrm{ml}^{-1}\right)$ in freshwater remained stable even after $4 \mathrm{~d}$ of incubation, and the cumulative mortality in the rock bream was more than $60 \%$. However, in seawater, the infectivity of both iridoviruses was sharply reduced after $4 \mathrm{~d}$ of incubation, and no cumulative mortality was induced in rock bream. It is notable that PGIV-SP incubated for 0 to $3 \mathrm{~d}$ induced $100 \%$ cumulative mortality in the rock bream within 2 wk of the challenge. This level of cumulative mortality was not different from that induced by IVS-1. Rock bream challenged with PGIV-SP displayed the same signs of iridovirus infec-

Table 2. Comparison of the viral copy numbers (average, repeated 3 times for each sample) by real-time PCR for PGIV-SP and IVS-1 maintained in seawater or freshwater for $4 \mathrm{~d}$ at $25^{\circ} \mathrm{C}$. $C_{\mathrm{T}}$ : detection threshold cycle

\begin{tabular}{|lccccc|}
\hline \multirow{2}{*}{ Medium } & \multirow{2}{*}{ Sampling time } & \multicolumn{2}{c|}{ PGIV-SP } & \multicolumn{2}{c}{ IVS-1 } \\
& & $C_{\mathrm{T}}$ value & Copy no. $\mathrm{mg}^{-1}$ & $C_{\mathrm{T}}$ value & Copy no. mg \\
\hline \multirow{2}{*}{ Freshwater } & Before filtration & 10.95 & $2.52 \times 10^{8}$ & 10.98 & $2.46 \times 10^{8}$ \\
& Day 0 & 16.60 & $3.98 \times 10^{6}$ & 16.73 & $3.61 \times 10^{6}$ \\
Seawater & Day 4 & 18.44 & $1.03 \times 10^{6}$ & 17.58 & $1.94 \times 10^{6}$ \\
& Before filtration & 11.03 & $2.37 \times 10^{8}$ & 11.14 & $2.19 \times 10^{8}$ \\
& Day 0 & 16.44 & $4.49 \times 10^{6}$ & 16.91 & $3.18 \times 10^{6}$ \\
& Day 4 & 24.02 & $1.72 \times 10^{4}$ & 24.15 & $1.56 \times 10^{4}$ \\
\hline
\end{tabular}




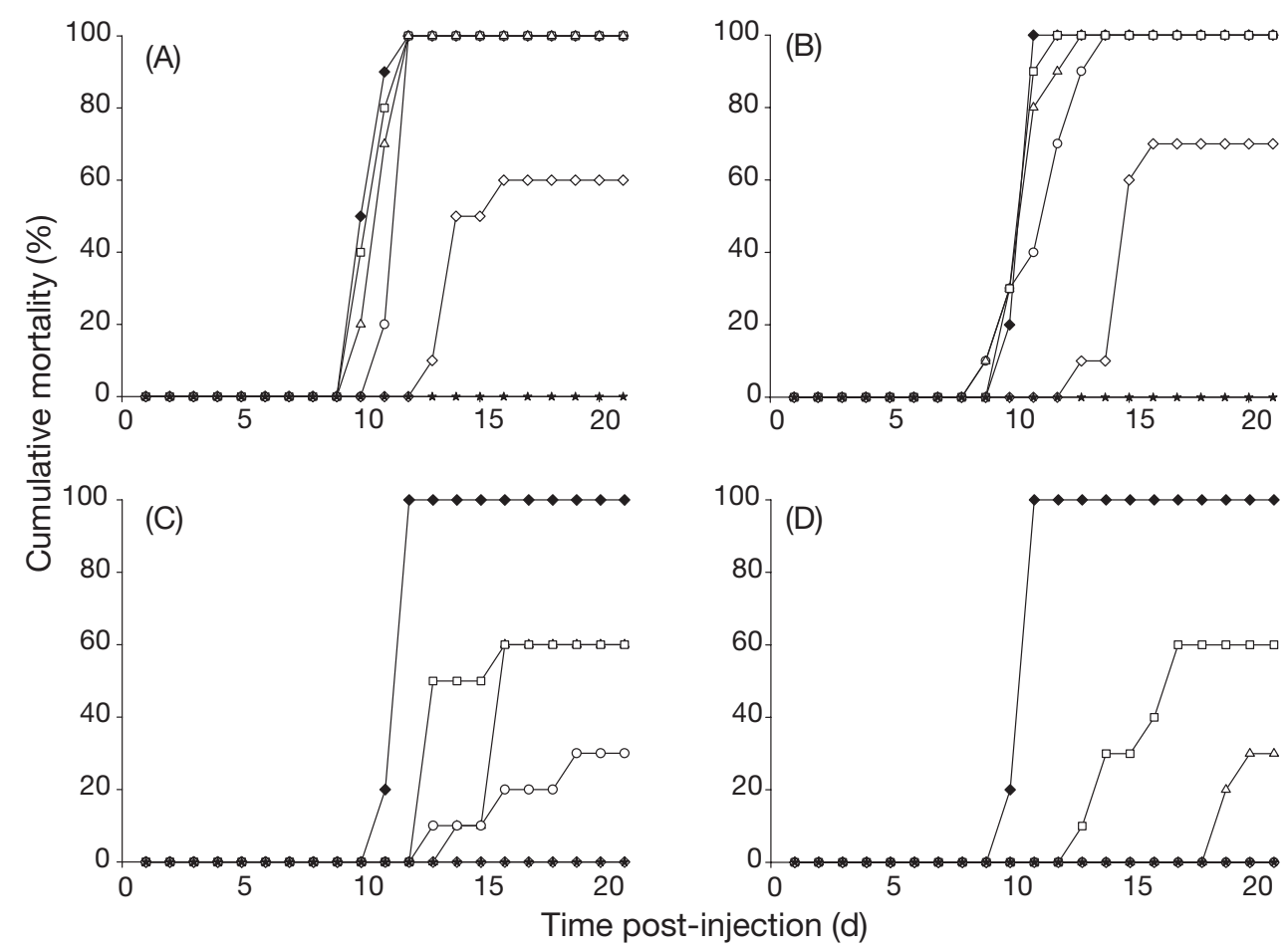

Fig. 1. Oplegnathus fasciatus. Cumulative mortality (\%) in rock bream challenged with (A,C) PGIV-SP or (B,D) IVS-1. A splenic homogenate from iridovirus-infected fish (100 $\mathrm{\mu g}$ infected spleen per fish) was injected intraperitoneally into rock bream after 0 $(\diamond), 1(\square), 2(\Delta), 3(O)$, or $4 \mathrm{~d}(\diamond)$ of incubation at $25^{\circ} \mathrm{C}$ in $(\mathrm{A}, \mathrm{B})$ freshwater or $(\mathrm{C}, \mathrm{D})$ seawater. Rock bream $(\star$ in $\mathrm{A}$ and $\mathrm{B})$ and pearl gourami ( $\star$ in $\mathrm{C}$ and $\mathrm{D}$ ) were also injected with PBS as a negative control

tion as those challenged with IVS-1, including the presence of enlarged cells in multiple organs (data not shown). In contrast, none of the fish injected with PBS died. Infection with PGIV-SP and IVS-1 was confirmed by PCR using the primer set SP1F/SP1R and by histopathological observation of enlarged cells in the spleen. All dead fish after viral infection were positive.

\section{Cohabitation}

Cohabitation experiments were performed to determine whether PGIV-SP, isolated from freshwater ornamental fish, could be passed to marine fish and whether IVS-1, isolated from marine fish, could be passed to freshwater ornamental fish (Fig. 2). When administered by IP injection into rock bream living in seawater and pearl gourami living in freshwater, both iridoviruses, IVS-1 and PGIV-SP, induced cumulative mortalities of 100 and $80 \%$, respectively. Death among the cohabitating rock bream/pearl gourami was delayed for 2 to $3 \mathrm{~d}$ and 9 to $10 \mathrm{~d}$, respectively, after the first appearance of dead fish among the intraperitoneally inoculated fishes. Significant differences in cumulative mortality were not detected between rock bream challenged with PGIV-SP and IVS-1. The cumulative mortality reached $100 \%$ among rock bream cohabitated with virus donors injected intraperitoneally with PGIV-SP or IVS-1. However, pearl gourami cohabitated with fish injected with PGIV-SP and IVS-1 showed reduced levels of cumulative mortality (60 and $30 \%$, respectively) compared to the cohabitating groups of rock bream.

\section{Discriminative PCR and the epidemiology of PGIV-SP infection in marine fish}

Two primer sets, SP1F/SP1R and SP2F/SP2R, were designed using the sequences of the conserved portions of the iridoviral K2 region (Jeong et al. 2006a). After PCR, the resulting amplicons from PGIV-SP and IVS-1, which were 929 and 1130 bp long, respectively, with the SP1F/SP1R primer set and 330 and $531 \mathrm{bp}$ long, respectively, with the SP2F/SP2R primer set, matched the expected sizes exactly (data not shown). After the sequence analysis of the K2 regions from PGIV-SP (data not shown), 2 additional sets of primers were designed from the K2 region, PGV1F/PGV1RPGV2F/PGV2R (specific for PGIV-SP) and SA1F/ SA1R-SA2F/SA2R (specific for IVS-1), which were 

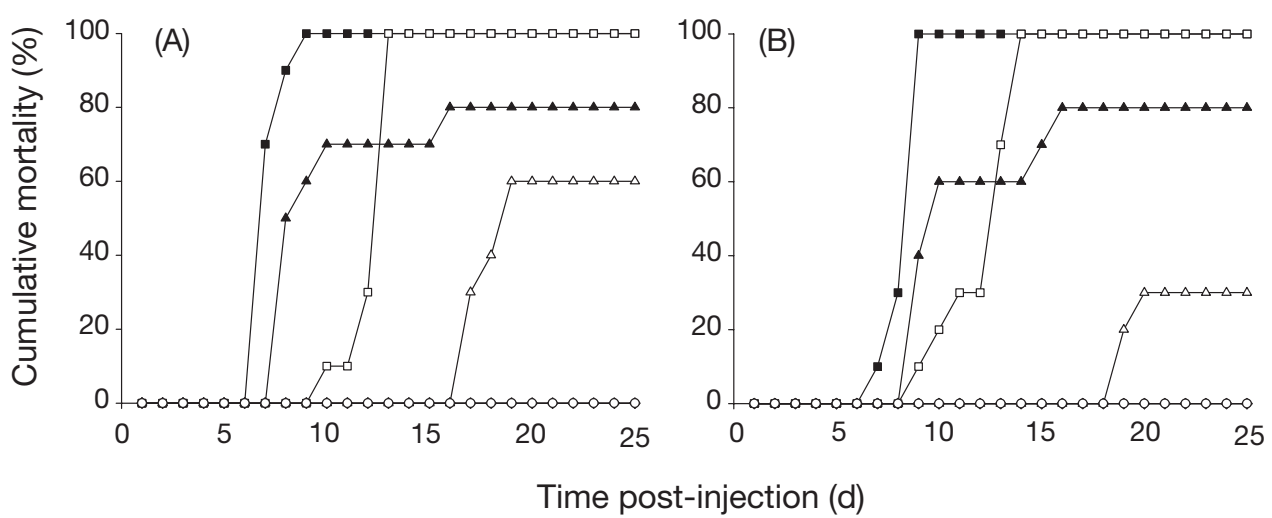

Fig. 2. Cumulative mortality (\%) of rock bream Oplegnathus fasciatus and pearl gourami Trichogaster leeri cohabitated or challenged with (A) PGIV-SP and (B) IVS-1, respectively. A splenic homogenate from iridovirus-infected fish (100 $\mu \mathrm{g}$ infected spleen per fish) was intraperitoneally injected into rock bream (ם) and pearl gourami $(\mathbf{\Delta})$. Normal rock bream $(\square)$ and pearl gourami $(\Delta)$ were cohabitated with challenged rock bream and pearl gourami, respectively. Rock bream $(\diamond)$ and pearl gourami $(O)$ were also injected intraperitoneally with $0.1 \mathrm{ml}$ PBS (pH 7.2) and held in separate $100 \mathrm{l}$ tanks as negative controls

Table 3. Prevalence of IVS-1 and PGIV-SP by single-step or 2-step PCR in 58 groups of 2 marine fish species purchased from markets in 2006

\begin{tabular}{|lccccccc|}
\hline Fish species & No. of & \multicolumn{3}{c}{ Single-step PCR } & \multicolumn{3}{c|}{ Two-step PCR } \\
& groups & Iridovirus & $\begin{array}{c}\text { IVS-1 } \\
\text { IVS-1 } \\
(+)\end{array}$ & $(+)$ & $\begin{array}{c}\text { PGIV-SP } \\
(+)\end{array}$ & $\begin{array}{c}\text { Iridovirus } \\
(-)\end{array}$ & $\begin{array}{c}\text { PGIV-SP } \\
(+)\end{array}$ \\
\hline Rock bream & 35 & 29 & 6 & 0 & 15 & 19 & 2 \\
$\begin{array}{l}\text { Oplegnathus fasciatus } \\
\text { Sea perch }\end{array}$ & & $(83 \%)$ & $(17 \%)$ & $(0 \%)$ & $(43 \%)$ & $(54 \%)$ & $(6 \%)$ \\
Lateolabrax sp. & 23 & 23 & 0 & 0 & 14 & 8 & 1 \\
& & $(100 \%)$ & $(0 \%)$ & $(0 \%)$ & $(61 \%)$ & $(35 \%)$ & $(4 \%)$ \\
\hline
\end{tabular}

used to confirm the specificity of the first round of amplification by producing amplicons 273 bp in length (Table 1). To obtain epidemiological data concerning PGIV-SP-like viral infections in marine fishes, 35 groups of rock bream (200 g) and 23 of sea perch (800 g) were sampled from various markets in 2006. All fish, which were clinically healthy, were tested for iridovirus infection by PCR immediately after collection. Six of the rock bream groups were found to be positive by single-step PCR using the IVS-1-specific primer set SA1F/SA1R, while 19 of the rock bream groups and 8 of the sea perch groups were found to be positive for IVS-1 by 2-step PCR (Table 3). None of the sea perch groups were found to be positive by single-step PCR. Surprisingly, 1 sea perch group and 2 rock bream groups obtained from different markets tested positive for PGIV-SP by 2-step PCR using the PGV2F/PGV2R primer set (Table 3, Fig. 3). Moreover, in an individual from 1 of the rock bream groups, both PGIV-SP and IVS-1 were detected. The amplicons obtained by 2step PCR of the K2 region from 3 PGIV-SP-positive samples and 5 randomly chosen IVS-1-positive samples, as well as 2 out of 6 IVS-1-positive samples identified by single-step PCR, were then sequenced. The sequence of the SP2F/SP2R region from the detected iridoviruses was more than 99\% homologous with those from IVS-1 and PGIV-SP (Fig. 4). The sequences of that region of iridoviruses isolated from 5 randomly chosen IVS-1-positive samples in 2-step PCR were identical to each other and to those of 2 positive samples in single-step PCR. Importantly, these results are the first to show the presence of PGIV-SP-like virus in marine fishes regarded as clinically healthy with or without IVS-1-like virus infection.

\section{DISCUSSION}

One of the most important factors governing the recovery and distribution of infectious viruses in commercially important marine aquaculture fish is their relative stability in seawater. The ability to survive in a seawater environment aids in the dissemination of the virus and may represent a potential route of viral disease transmission. To determine the stability of freshwater-borne megalocytiviruses in seawater, PGIV-SP obtained from the freshwater ornamental fish pearl gourami was discharged into seawater, and the viral 


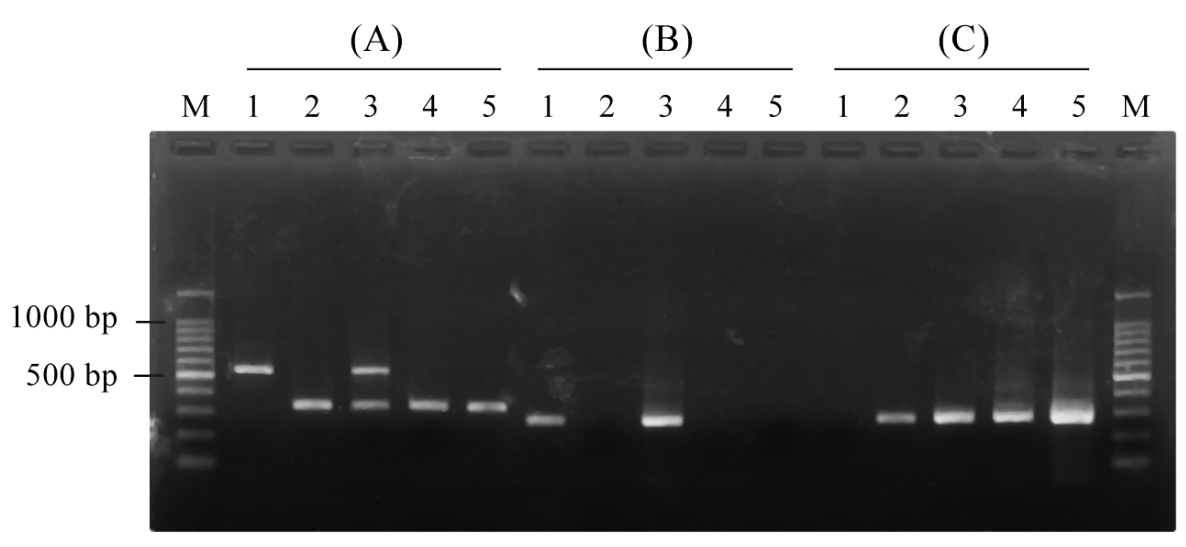

Fig. 3. Differentiation between IVS-1 and PGIV-SP in purchased marine fish by 2-step PCR using different primer sets (A: SP2F/SP2R; B: IVS2F/IVS2R; C: PGV2F/PGV2R). Lane 1: DNA from IVS-1; Lane 2: DNA from PGIV-SP; Lanes 3 and 4: DNA from an iridovirus isolated from purchased rock bream Oplegnathus fasciatus; Lane 5: DNA from an iridovirus isolated from purchased sea perch Lateolabrax sp.; Lanes M: 100 bp DNA ladder

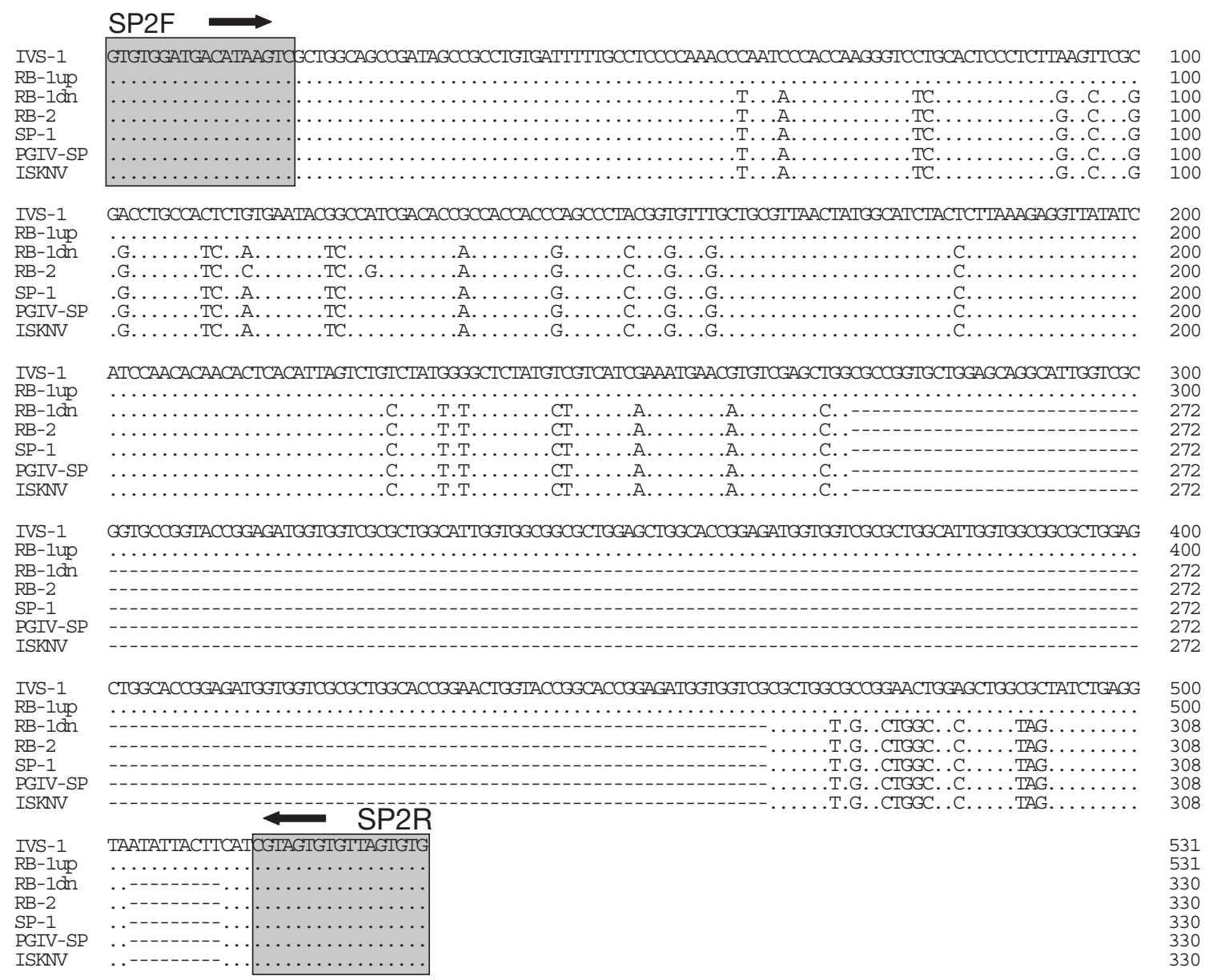

Fig. 4. Comparison of the ORF-1 gene from the K2 region in various iridoviruses. Dots: identical residues; dashes: gaps; boxes: positions of the second primer set (SP2F/SP2R) used in 2-step PCR. RB-1up and RB-1dn: IVS-1 and PGIV-SP, respectively, detected from an individual purchased rock bream Oplegnathus fasciatus; RB-2: iridovirus detected from purchased rock bream;

SP-1: iridovirus detected from purchased sea perch Lateolabrax sp.; ISKNV: infectious spleen and kidney necrosis virus 
genome copy number following incubation at $25^{\circ} \mathrm{C}$ was compared to that in freshwater by real-time PCR using double-stranded DNA binding dyes. The reverse experiment (i.e. the stability of seawater-borne megalocytiviruses in freshwater) was done using IVS-1 obtained from rock bream. The viral genome concentrations in the spleens of rock bream and pearl gourami infected with PGIV-SP and IVS-1 $\left(2.52 \times 10^{8}\right.$ and $2.46 \times 10^{8}$ copies $\mathrm{mg}^{-1}$ spleen, respectively) were not significantly different from each other but were higher than that of iridovirus $\left(6.86 \times 10^{6}\right.$ copies $\mathrm{mg}^{-1}$ spleen) in large yellow croaker Pseudosciaena crocea (Wang et al. 2006). This may be due to differences in the host species, virus type, or infection stage. The number of iridoviral particles in commercially important fish has not previously been compared with each other in other laboratories. In terms of stability, the decrease in viral copy number after discharge into seawater was much higher than that after discharge into freshwater (Table 2) for both PGIV-SP and IVS-1. However, to obtain meaningful information regarding infectivity from variations in the viral genome copy number, a comparison that includes the change in $\mathrm{TCID}_{50}$ (50\% tissue culture infective dose) during incubation might be important. Unfortunately, in previous experiments at our laboratory (unpubl.), the virus titer decreased rapidly in subcultures of the GF-1 cell line, as was reported by other laboratories for the BF-2 cell line (Nakajima \& Sorimachi 1994), and the KRE cell line, which was derived from hybrid grouper (Chou et al. 1998). In the present study, we used a challenge experiment, which may be a more definitive in vivo test, to confirm that the decrease in copy number indicated by real-time PCR in our in vitro analysis was responsible for the decreased cumulative mortality of rock bream after IP injection with iridovirus incubated in seawater or freshwater. Moreover, in our cohabitation experiments (Fig. 2), the successful transmission of PGIV-SP and IVS-1 from donor to cohabitant implies that dissemination of iridoviruses (i.e. PGIV-SP to rock bream in a seawater environment and IVS-1 to pearl gourami in a freshwater environment) may be possible in the natural environment.

Since fish are transported worldwide for commercial and ornamental use, it is possible that one or more species may be the vehicle by which iridovirus is introduced to a new host or environment (Mao et al. 1999). However, there are no restrictions on the importation of freshwater ornamental fish into Korea or most other countries, except for Australia and New Zealand. In addition, few studies have addressed the potential for mass mortality in the marine aquaculture industry caused by iridoviruses from ornamental fish species. Surprisingly, Murray cod iridovirus (MCIV) was detected in paraffin-embedded tissues from Murray cod
Maccullochella peelii peelii that died during an epizootic outbreak in Australia in 2006 (Go et al. 2006). The MCP gene of MCIV is nearly $100 \%$ homologous $(99.95 \%)$ with that of dwarf gourami Colisa lalia iridovirus (DGIV) imported from Southeast Asia (Go et al. 2006), suggesting a link between the ornamental fish trade and emerging iridoviral diseases. Thus, the results of the present study may provide evidence for the risk of cross-infection by PGIV-SP (or IVS-1) in both seawater and freshwater fish.

Given these data, it is important to assess whether the Megalocytivirus spp. found in freshwater ornamental fish may have already been introduced into farmed marine fish populations. Although there is no report of an ornamental fish-derived iridoviral disease associated with high mortality in the Korean marine aquaculture industry, testing for iridoviral DNA in marine fish might indicate whether the iridoviruses found in ornamental fish have already been introduced into the marine aquaculture industry, and whether there is a genetic relationship between the strains found in Korean ornamental fish. As far as we are aware, there is no report of mass mortality in a natural environment in Korea due to iridoviral strains assumed to be derived from ornamental fish species. However, asymptomatic viral infections with the Ranavirus LMBV in largemouth bass (Hanson et al. 2001) and the Megalocytivirus IVS-1 (Jeong et al. 2006b) have previously been shown to be associated with mass mortality. Thus, it is worth considering asymptomatic infections in order to determine the presence of iridoviruses, which are found only in freshwater ornamental fish, in marine environments. Using discriminative PCR and sequence analysis, we identified 3 samples, 1 in sea perch and 2 in rock bream, which contained PGIV-SP-like genomic DNA among 58 sample groups collected from apparently healthy fish (Fig. 3). The 3 PGIV-SP-like viruses shared greater than 99\% homology (Fig. 4) in their ORF-1 genes and should thus be grouped together under the genus Megalocytivirus as subgroup 3 (ISKNV-related; Imajoh et al. 2007). Although an ISKNV-like virus was recently detected in marine fish in China by 2-step PCR (Wang et al. 2007), our results are the first to show the presence of an asymptomatic infection of PGIV-SP-like virus in cultured marine fish species in Korea. We cannot exclude the possibility that the PGIV-SP and PGIV-SP-like viruses we identified in our samples might be included among the ISKNV-like viruses of Wang et al. (2007) due to the high level of homology they share with ISKNV in terms of their MCP gene. The pathogenicity of ISKNV examined by infection trials in 21 teleosts and, except for freshwater fish such as the mandarinfish and largemouth bass, did not induce 
mortality in any marine fish species used ( $\mathrm{He}$ et al. 2002). However, direct trials of infection with the iridovirus strain isolated from the diseased ornamental fish, like PGIV-SP, to the marine fish species have not been performed. Thus, results of the present study allowed us to assume that PGIV-SP showed a different host range and pathogenicity from those of ISKNV and should be considered as one of the distinctive strains in the clusters or subgroup 3 (Imajoh et al. 2007) of the ISKNV-related iridoviruses.

It is difficult to determine the relationship between PGIV-SP-related mass mortality and the prevalence of asymptomatic infections with PGIV-SP-like viruses in marine fish species. However, it should be noted that the marine species rock bream was susceptible to PGIV-SP isolated from pearl gourami and showed a high cumulative mortality (Figs. 1 \& 2). Thus, the infection of marine fish with PGIV-SP-like viruses may not be limited to cases of asymptomatic infection; instead, it may pose a risk for mass mortality throughout the entire marine aquaculture industry. The reverse situation (i.e. the infection of freshwater ornamental fish with iridoviruses from marine fish) may also pose the same risk to ornamental fish species.

In summary, the virulence and stability of PGIV-SP obtained from pearl gourami and IVS-1 from rock bream were compared both in vitro and in vivo by quantitative PCR and induced mortality.

In addition, the infection of Korean freshwater ornamental fish with PGIV-SP, or ISKNV of the type found in Chinese mandarinfish, was identified in externally healthy rock bream and sea perch. These data should be examined further as to whether natural outbreaks are occurring with high mortality in the marine aquaculture fish industry.

Acknowledgements. This research was supported by a grant (2007, M2007-07) from the Marine Process Research Center of the Marine Bio 21 Center funded by the Ministry of Maritime Affairs and Fisheries, Republic of Korea.

\section{LITERATURE CITED}

Bloch B, Larsen JL (1993) An iridovirus-like agent associated with systemic infection in cultured turbot Scophthalmus maximus fry in Denmark. Dis Aquat Org 15:235-240

Chen XH, Lin KB, Wang XW (2003) Outbreaks of an iridovirus disease in maricultured large yellow croaker Larimichthys crocea (Richardson), in China. J Fish Dis 26: 615-619

Chinchar G, Essbauer S, He JG, Hyatt A, Miyazaki T (2005) Family iridoviridae. In: Fauquet CM, Mayo MA, Maniloff J, Desselberger U, Ball LA (eds) Virus taxonomy classification and nomenclature of viruses. 8th Rep Int Comm Taxon Viruses. Academic Press, San Diego, CA, p 145-161

Chou HY, Hsu CC, Peng TY (1998) Isolation and characteriza- tion of a pathogenic iridovirus from cultured grouper (Epinephelus sp.) in Taiwan. Fish Pathol 33:201-206

Chua FHC, Ng ML, Ng KL, Loo JJ, Wee JY (1994) Investigation of outbreaks of a novel disease, 'sleepy grouper disease', affecting the brown-spotted grouper, Epinephelus tauvina Forskal. J Fish Dis 17:417-427

- Do JW, Moon CH, Kim HJ, Ko MS and others (2004) Complete genomic DNA sequence of rock bream iridovirus. Virol 325:351-363

> Go J, Lancaster M, Deece K, Dhungyel O, Whittington R (2006) The molecular epidemiology of iridovirus in Murray cod (Maccullochella peelii peelii) and dwarf gourami (Colisa lalia) from distant biogeographical regions suggests a link between trade in ornamental fish and emerging iridoviral diseases. Mol Cell Probes 20:212-222

Hanson LA, Petrie-Hanson L, Meals KO, Chinchar VG, Rudis M (2001) Persistence of largemouth bass virus infection in a northern Mississippi reservoir after a die-off. J Aquat Anim Health 13:27-34

He JG, Wang SP, Zeng K, Huang ZJ, Chan SM (2000) Systemic disease caused by an iridovirus-like agent in cultured mandarinfish, Siniperca chuatsi (Basilewsky), in China. J Fish Dis 23:219-222

- He JG, Deng M, Weng SP, Li Z and others (2001) Complete genome analysis of the mandarinfish infectious spleen and kidney necrosis iridovirus. Virol 291:126-139

> He JG, Zeng K, Weng SP, Chan SM (2002) Experimental transmission, pathogenicity and physical-chemical properties of infectious spleen and kidney necrosis virus (ISKNV). Aquaculture 204:11-24

Imajoh M, Ikawa T, Oshima SI (2007) Characterization of a new fibroblast cell line from a tail fin of red sea bream, Pagrus major, and phylogenetic relationships of a recent RSIV isolate in Japan. Virus Res 126:45-52

Inouye K, Yamano K, Maeno Y, Nakajima K, Matsuoka M, Wada Y, Sorimachi M (1992) Iridovirus infection of cultured red sea bream, Pagrus major. Fish Pathol 27:19-27 (in Japanese with English Abstract)

Jeong JB, Kim HY, Kim KH, Chung JK, Komisar JL, Jeong HD (2006a) Molecular comparison of iridoviruses isolated from marine fish cultured in Korea and imported from China. Aquaculture 255:105-116

Jeong JB, Jun LJ, Park KY, Kim KH, Chung JK, Komisar JL, Jeong HD (2006b) Asymptomatic iridovirus infection in various marine fishes detected by a 2-step PCR method. Aquaculture 255:30-38

Kurita J, Nakajima K, Hirono I, Aoki T (1998) Polymerase chain reaction (PCR) amplification of DNA of red sea bream iridovirus (RSIV). Fish Pathol 33:17-23

Mahardika K, Zafran, Yamamoto A, Miyazaki T (2004) Susceptibility of juvenile humpback grouper Cromileptes altivelis to grouper sleepy disease iridovirus (GSDIV). Dis Aquat Org 59:1-9

Mao J, Green DE, Fellers G, Chinchar VG (1999) Molecular characterization of iridoviruses isolated from sympatric amphibians and fish. Virus Res 63:45-52

Munir K (2006) Characterization of Chinook head salmon embryo phenotypes of infectious salmon anemia virus by real-time RT-PCR. J Vet Sci 7:167-176

Nakajima K, Sorimachi M (1994) Biological and physicochemical properties of the iridovirus isolated from cultured red sea bream, Pagrus major. Fish Pathol 29:29-33

> Nerland AH, Skaar C, Eriksen TB, Bleie H (2007) Detection of nodavirus in seawater from rearing facilities for Atlantic halibut Hippoglossus hippoglossus larvae. Dis Aquat Org 73:201-205

Oshima S, Hata J, Hirasawa N, Ohtaka T, Hirono I, Aoki T, 
Yamashita S (1998) Rapid diagnosis of red sea bream iridovirus infection using the polymerase chain reaction. Dis Aquat Org 32:87-90

Pallister J, Gould A, Harrison D, Hyatt A, Jancovich J, Heine H (2007) Development of real-time PCR assays for the detection and differentiation of Australian and European ranaviruses. J Fish Dis 30:427-438

Paperna I, Vilenkin M, de Matos APA (2001) Iridovirus infections in farm-reared tropical ornamental fish. Dis Aquat Org 48:17-25

Sudthongkong C, Miyata M, Miyazaki T (2002) Iridovirus disease in two ornamental tropical freshwater fishes: African lampeye and dwarf gourami. Dis Aquat Org 48:163-173

Editorial responsibility: Julie Bebak, Auburn, Alabama, USA
Wang XW, Ao JQ, Li QG, Chen XH (2006) Quantitative detection of a marine fish iridovirus isolated from large yellow croaker, Pseudosciaena crocea, using a molecular beacon. J Virol Methods 133:76-81

- Wang YQ, Lu L, Weng SP, Huang JN, Chan SM, He JG (2007) Molecular epidemiology and phylogenetic analysis of a marine fish infectious spleen and kidney necrosis viruslike (ISKNV-like) virus. Arch Virol 152:763-773

Weng SP, Wang YQ, He JG, Deng M and others (2002) Outbreaks of an iridovirus in red drum, Sciaenops ocellata (L.), cultured in southern China. J Fish Dis 25: 681-685

> Williams T (1996) The iridoviruses. Adv Virus Res 46:345-412

Submitted: January 28, 2008; Accepted: June 27, 2008

Proofs received from author(s): September 15, 2008 